\title{
Soanian tools in northwestern sub-himalayas are not that old
}

\section{Introduction}

In an attempt to understand the geological contexts of the stone tools recovered from NW sub-Himalays was first made by de Terra \& Paterson ${ }^{1}$ and this British-American team was also responsible for assigning cultural labels to some of these lithic assemblages as 'Soan' or 'Soanian'., 2,3 De Terra \& Paterson' broadly placed the origin of these Soanian tools in the Middle Pleistocene.,5 The research involving this region made by de Terra \& Paterson ${ }^{1}$ was supplemented by Paterson \& Drummond, ${ }^{6}$ Graziosi, ${ }^{7} \mathrm{Krantz}^{8}$ which resulted in various cultural stages of the Soanian as; Pre-Soan, Early Soan, Late-Soan etc., with further sub-stages and were thought to be a result of the glacial and inter-glacial periods. In Pakistan, subsequent Paleolithic investigations took place in the Soan valley, the Potwar Plateau, the Pabbi Hills, and the Rohri Hills in the Sind region..$^{9,10}$ In India, most investigations took place in the river valleys of Sutlej, Ravi Saroj, ${ }^{11}$ Markanda Joshi et al., ${ }^{12}$ Beas-Banganga Lal, ${ }^{13}$ Sirsa, and Soan ('Swan' of Indian Punjab), and in the intermontane dun valleys. ${ }^{14-16}$ Most of the workers in India ${ }^{14,16,17}$ relied heavily on de Terra and Paterson's work, ${ }^{1}$ ultimately resulting in oversimplified and confusing cultural interpretations. ${ }^{18}$ A general view was presented that the Early-Soan consisted of heavy duty tools with the dominance of choppers and in the Late-Soan, the occurrence of flakes/flaketools increased and the tools became smaller in size. ${ }^{1,19,20}$ The LateSoan of the Soan valley of north Pakistan is also considered to be belonging to South Asian Middle palaeolithic tradition in typological terms. ${ }^{21,22}$ The typochronological distinction between Early and LateSoan is still not clear because both the tool-types mixed with each other have only been reported in un-datable surface contexts. Doubts about de Terra and Paterson's observations first surfaced only through the works of Gill \& Sankalia. ${ }^{23,24}$ The stratigraphical context of the Soanian industries as first specified by de Terra \& Paterson ${ }^{1}$ was severely questioned by later field studies Rendell et al. ${ }^{10}$ The Soan River 'terraces' as observed by de Terra and Paterson were proven to be erosional features rather than true river terraces Rendell et al ${ }^{10}$ As a result, Soanian technological evolution de Terra \& Paterson ${ }^{1}$ is no longer considered to be valid. ${ }^{10,25,26}$ There is no evidence of discrete 'Early' or 'Late' Soan entities since the Soanian tools including both large and small types and with varying flake contents have also been found recently even from very young sites..$^{27-32}$

Virtually all the previously reported Palaeolithic sites in this region were known in un-datable surface contexts, and the resulting collections are often inadequate for accurate techno-typological or typochronological analyses. New findings by the present authors have been made in dated context and astonishingly, the results obtained are quite at variance with the earlier (partially) established views. We discovered that late-Hrappans were manufacturing and using stone tools Soni \& Soni, ${ }^{33}$ most of them has been called as Soanian; may be Soanian tools are not that old as has generally been addressed for long. Most fresh tools have been discovered by us from young dated sites and some recent claims Gaillard et al. ${ }^{34}$ that tools found from Quranwala Zone of NW sub-Himalayas are of late-Pliocene times have been proved by us to be of sub-recent times Soni \& Soni. ${ }^{32}$
Volume I Issue 4 - 2017

\author{
Anujot Singh Soni, 'Vidwan Singh Soni ${ }^{2}$ \\ 'University College, India \\ ${ }^{2}$ Urban Estate, India
}

Correspondence: Vidwan Singh Soni, Urban Estate, India, Email vidwansoni@gmail.com

Received: August 18, 2017 | Published: December 12, 2017

Actually during the mid-Holocene Global arid phase ${ }^{35,36}$ the lateHarappans mostly shifted to the sub-Himalays in search of water sources. Between 3.9 and $3.0 \mathrm{ka}$, there was a proliferation of smaller, village-type settlements ${ }^{37-39,35}$ (Figure 1), especially in the Himalayan foothills and the western part of the Ganges. During late phase the long-distance trade was almost absent and the production of a wide range of material was curtailed Possehl..$^{38}$ It is also possible that during long spells of drought the procurement of metal for day to day work could also have also become almost difficult for the lateHarappans; particularly for those who shifted to remote places in the sub-Himalayas. They started manufacturing and using stone tools which were mostly the (so called) Soanian types. This view is confirmed by the discovery of such tools from a late-Harappan site Bara (Figure 1). Bara site in dist Ropar (Punjab-India) consists of an archaeological mound which is known for a typical late-Harappan 'Bara-Ware' (Allchin \& Allchin). ${ }^{21}$ It is the pottery of this site which is most distinctive and diagnostic (Sharma 1981). This 4m high mound is situated in Punjab plains about $8 \mathrm{~km}$ in the southwest of the Siwalik frontal-range. The site was previously situated on the left bank of a stream 'Budki-Nadi' which has since shifted towards north by about $1 \mathrm{Km}$. In the year 2008 , we visited this site. Surprisingly, we found some stone tools on the surface of that archaeological mound (Soni \& $\mathrm{Soni}^{27}$ ) which included a few choppers, scrapers, a point, and many utilized flakes resembling the Soanian arte facts made on coarse-grained quartzite which are known to exist in the neighboring Siwaliks. The excavation has yet been discontinued, but the excavators informed us Nauriyal et al..$^{33}$ that they recovered more such stone tools from just a small depth so far excavated. Though the Bara mound has been excavated twice (1955 and 1971) by Sharma A S I, ${ }^{40}$ the presence of any stone tool is not mentioned in the material excavated from this site dated to late mid-Holocene Agrawal \& Kusumgar. ${ }^{41}$ The scarcity of metal in this site is supported by the fact that only 2 pieces of copper, a fishing hook and a fragmentary bangle, were recovered from the excavated material Sharma. ${ }^{42}$ That is probably why the Bara occupants were using the stone tools as they could not harnsss metal from anywhere.

Another late-Harappan site that we explored was Dher Majra which was first discovered by Olaf Prufer. ${ }^{43}$ The Dher-Majra site is situated on the left bank of an unnamed short-run ephemeral tributary of Kanhan Nadi (Figure 1), both of which emanate from the Siwalik Frontal-Range and join Sirsa Nadi originating from the Upper Siwalik foothills of the Himalayas. At present the mound at that site has 
almost been leveled by local people but its remnant part is still higher than the surface of the lower terrace (called T-3 by Olaf Prufer). Fresh looking unrolled Soanian type stone tools as well as potsherds eroded out of the mound are seen littered all over there, and same tools were collected by Prufer ${ }^{43}$ from the mound-top. Therefore, the only possibility is that Prufer's findings Prufer $^{43}$ were a part of the culture of that mound. Some Harapppan potsherds with Soanian tools were found from a young terrace of Sirsa Nadi near Dhang also, a place closes to Dher Majra.

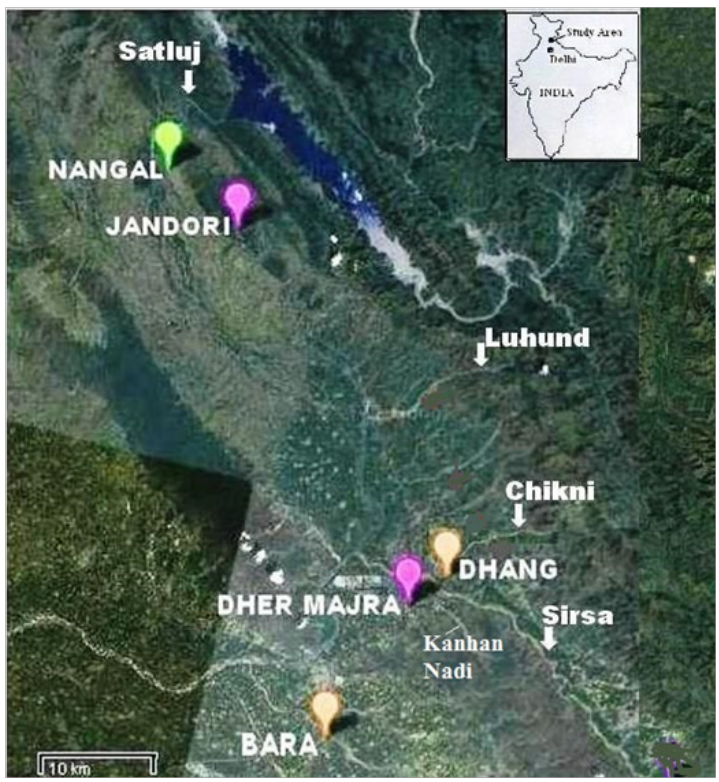

Figure I Sites discussed in this presentation.

An important site complex was discovered by us on a young dated terrace sequence of River Satluj near Nangal (Punjab; India). Three terraces are visible on the left bank of River Satluj above its flood plain near Nangal Township. Lowest terrace site named NGT-1 is on first terrace and the sites NGT-2 and NGT-3 are respectively on next two higher terraces. The riverside edge of first terrace (site NGT-1) is about $9 \mathrm{~m}$ above the present river bed, the next higher terrace NGT- 2 is nearly $10 \mathrm{~m}$ above the south end of terrace NGT-1 and the edge of NGT3 is about $9 \mathrm{~m}$ above the left end of site NGT-2. Initially the sediment of all the three terraces was deposited by River Satluj in the form of pebble-boulder gravel and subsequently three incision events gave the terraces their present morphology. The first incision event started well before $11.3 \mathrm{ka}$ and ended around $11.3 \mathrm{ka}$ giving rise to remnant terraces NGT-3 and NGT-2. The terrace NGT-2 is cut-in-fill terrace whose topmost layer is muddy sediment drawn from the background hill. The muddy sediment went on depositing on the gravel-bottom during Holocene until a little after 4.8ka. Two soil samples taken at different depths of NGT- 2 gave OSL dates; $4.79 \pm 0.6 \mathrm{ka}$ at $55 \mathrm{~cm}$ depth, and $11.31 \pm 1.8 \mathrm{ka}$ at a depth of $1.35 \mathrm{~m}$ (Table 1$)$.

Many new tool types have also been discovered by us along with the usually known Soanian tools from these Nangal sites situated on the mid-Holocene terraces on the left bank of the Satluj River (which were either not encountered by earlier workers from anywhere or were ignored by them). In addition, the Black \& Red Ware potsherds, reported from late mid-Holocene sites elsewhere ${ }^{44,45}$ and weathered red ware with coarse fabric (some resembling the pieces of Harappan pottery) have also been found from all the three sites mentioned above. Pitted cobbles, which have first time been reported to have existed in the Northwestern sub-Himalayas Soni \& Soni, ${ }^{30,32}$ were already known from many sites in the world. ${ }^{46-48}$ Such artefacts found from Northern and central California were associated with milling stones and a lot of casual artifacts containing among others, the scrapers, knives, points and cutting tools Fitzgerald \& Jones. ${ }^{47}$ The sites of those findings have been dated from mid to late mid-Holocene. Such tools found from Nangal site complex also points to their simultaneous occurrence at global level. But the Soanian tools were abundantly found from these terrace surfaces dated to mid-Holocene.

Table I OSL dating of Soil Samples of mud deposition on the upper terrace of Satluj at Nangal. Material-Sediment sample: Mineral used -Quartz Size: $90-$ I25 micrometer SAR protocol (Murray and Wintle, Rad. Mea. 2000)

\begin{tabular}{|c|c|c|c|c|c|c|c|c|}
\hline Lab no. & $\begin{array}{l}\text { Sample depth from } \\
\text { Surface }(\mathrm{cm})\end{array}$ & $\mathbf{U}(\mathrm{ppm})$ & $\begin{array}{l}\text { Th } \\
\text { (ppm) }\end{array}$ & K (\%) & $\begin{array}{l}\text { Moisture } \\
\text { content (\%) }\end{array}$ & $\begin{array}{l}\text { Equivalent } \\
\text { dose (De)Gy }\end{array}$ & $\begin{array}{l}\text { Dose rate } \\
\text { (Gy/ka) }\end{array}$ & Age (ka) \\
\hline LD874 & 55 & $2.64 \pm 0.3$ & $|4 \pm| .4$ & $1.64 \pm 0.2$ & 7.06 & $14.84 \pm 1.6$ & $3.10 \pm 0.2$ & $4.79 \pm 0.6$ \\
\hline LD873 & 135 & $2.12 \pm 0.2$ & $20 \pm 2$ & $1.55 \pm 0.2$ & $1.4 \mid$ & $39.25 \pm 5.8$ & $3.47 \pm 0.2$ & $\mid 1.31 \pm 1.8$ \\
\hline
\end{tabular}

Jandori-6 is a site situated in the middle siwaliks indist. Bilaspur of Himachal Pradesh (India) which was excavated by us during 200304 field sessions. A limited excavation of this site (of $1.5 \mathrm{sq}$ meter area and $1.8 \mathrm{~m}$ depth) yielded around 3 thousand stone artefacts along with some potsherds. Some of the potsherds resembled the Harappan types Soni \& Soni, ${ }^{33}$ There were also present many edge-ground artefacts $(n=732)$ in the total assemblage of about five thousand surficial/excavated lithic specimens. Site Jandori-6 appears to have experienced a phase of aridity in the past since all the lithic specimens and the potsherds below $30 \mathrm{~cm}$ of the top of the trial trench were laden with $\mathrm{CaCO}_{3}$. It shows that the artefacts in the lower layers had collected there as a creep wash during aridity (which makes $\mathrm{CaCO}_{3}$ to deposit on them) and hints at the fact that the site could have been occupied by hominines during some mid-Holocene arid phase. The occurrence of Harappan pottery along with Soanian-like stone tools (though there were edge-ground tools also) in-situ also points to the presence of Harappans at the site. One date of a potsherd obtained by OSL method (Table 2) also falls in mid-Holocene. Jandori-6 is as such a first mid-Holocene site in which edge-ground tools were found in association with the Soanian tools and Harappan potsherds. In southeast Asia, mostly core tools and occasionally flakes with an edge-gloss are reported in upper stages of the, ${ }^{49,50}$ but here in Jandori-6 assemblage, the edge-ground tools are abundantly the flakes $(>95 \%)$ and flake tools. This place was a factory site which is evidenced by the presence of about $2.5 \mathrm{Kg}$ of lithic shatter found in the excavated material.

Table 2 OSL dating of a Potsherd excavated from the site Jandori-6. Material-Pottery: Mineral used-Quartz: Size: 90-I25 micrometer: SAR protocol (Murray and Wintle, Rad. Mea. 2000)

\begin{tabular}{lllllllll}
\hline Lab no. & $\begin{array}{l}\text { Sample } \\
\text { depth }(\mathbf{c m})\end{array}$ & $\mathbf{U}(\mathbf{p p m})$ & Th $(\mathbf{p p m})$ & $\begin{array}{l}\text { Potassim } \\
\text { K \% }\end{array}$ & $\begin{array}{l}\text { Moisture } \\
\text { content (\%) }\end{array}$ & $\begin{array}{l}\text { Equivalent dose } \\
\text { (E.D.) Gy }\end{array}$ & $\begin{array}{l}\text { Dose rate } \\
\text { (Gy/ka) }\end{array}$ & Age (ka) \\
\hline LD637 & 60 & $4.35 \pm 0.44$ & $19.02 \pm 1.9$ & $1.98 \pm 0.2$ & 1 & $21.41 \pm 1.52$ & $4.51 \pm 0.27$ & $4.744 \pm 0.437$ \\
\hline
\end{tabular}




\section{Conclusion}

The results obtained from above mentioned 4 dated sites show that the Soanian and some other stone tools previously ignored/not encountered ${ }^{51}$ by earlier researchers did actually occur mostly during the mid-Holocene times. There were many undated sites also which yielded the same tyoplogy of tools, but they in fact belong to midHolocene (by comparison). The earlier reporting was based on $^{52}$ inadequate investigations with meagre surface collections from here and there and no attempt was made (or there were no provisions available) to date the sites. The inferences stating the occurrence of Soanian tools during mid to late Pleistocene were merely based on speculations like comparing the terraces of Rivers Soan's or Satluj with the outdated Alpine Galaciation chronology. The true analysis (as done by us) indicates that the Soanian tools were not that old, since they have been abundantly found from mid-Holocene sites as mentioned above.

\section{Acknowledgements}

None.

\section{Conflict of interest}

The author declares no conflict of interest.

\section{References}

1. De-Terra H, Paterson TT. Studies on the Ice Age in India and Associated Human Cultures (Carnegie Institute Publication 493). USA: Carnegie Institute; 1939.

2. Hawkes J, Hawkes C, De Terra H. Palaeolithic human industries in the Northwest Punjab and Kashmir and their geological significance: Memoirs of the Connecticut Academy of Arts and Sciences III:1-13. New Haven: Connecticut Academy of Arts and Sciences; 1934

3. Movius HL. The Lower Palaeolithic cultures of Southern and Eastern Asia. Transactions of the American Philosophical Society. 1948;38(4):329-420.

4. Dennell RW, Rendell HM. De Terra and Paterson and the Soan Flake industry: a new perspective from the Soan Valley, Northern Pakistan. Man and Environment. 1991;16(2):90-99.

5. Dennell RW, Hurcombe L. Paterson, the British Clactonian and the Soan Flake Industry: are-evaluation of the Early Palaeolithic of Northern Pakistan. In: Jarrige C, editor. South Asian Archaeology. USA: Prehistory Press; 1993. p. 69-72.

6. Paterson TT, Drummond HJH. Soan the Palaeolithic of Pakistan Department of Archaeology, Government of Pakistan, Karachi, Pakistan 1962.

7. Graziosi P. Prehistoric Research in North-Western Punjab Scientific Reports of the Italian Expeditions to the Karakorum (K2) and Hindukush. Netherlands: EJ Brill; 1964.

8. Krantz G. Soan tool types from Ghila Khan. Asian Perspectives. 1972;15:66-82.

9. Stiles D. Palaeolithic artifacts in Siwalik and post-Siwalik deposits. Kroeber Anthropology Society. 1975;53-54:129-148.

10. Rendell HM, Dennell RW, Halim MA. Pleistocene and Palaeolithic Investigations in the Soan Valley, Northern Pakistan. British Archaeological Mission to Pakistan Series 2. Oxford: B A R International Series 544; 1989.
11. Saroj HM. Lithic Industry of Jammu: Unpublished Ph.D. Thesis. India: Punjab University Library; 1974.

12. Joshi RV, Rajaguru SN, Badam GL, et al. Early and Middle Palaeolithic tools from river terraces in the Saketi Area. Markanda Valley, H.P. Current Science. 1975;44(13):464-465.

13. Lal BB. Palaeoliths from Beas and Banganga Valleys, Panjab. Ancient India. 1956;12:58-92.

14. Mohapatra GC, Singh M. Prehistoric Investigations in a Sub-Himalayan Valley, Himachal Pradesh, India. Current Anthropology. 1979;20:600 602.

15. Karir BS. Geomorphology and Stone Age Culture of Northwestern India. India: Sundeep Prakashan; 1985

16. Singh M, Karir BS, Chopra SN. Prehistoric and Quaternary Studies of the Roop Nagar District of Punjab. India: Department of Cultural Affairs, Archaeology and Museums (unpublished report); 1998.

17. Mohapatra GC. Acheulian discoveries in the Siwalik frontal range. Current Anthropology. 1981;22:433-435.

18. Misra VN, Mate MS. Indian Prehistory: 1964. India: Deccan College Post-graduate and Research Institute; 1995.

19. Mohapatra GC. Lithic industries of Himachal Pradesh. In: Ghosh AK editor. Perspective in Palaeoanthropology. India: KL Mukhopadyay; 1974. p. 199-212.

20. Mohapatra GC. Lithic cultures of the sub-Himalayas. In: Sankhyan AR Rao VR, editors. Human Origins, Genome and People of India. India: Allied Publishers; 2007. p. 138-143.

21. Allchin B, Allchin R. The rise of civilization in India and Pakistan. England: Cambridge University Press (South Asian Edition); 1996.

22. Lycett SJ. Is the Soanian techno-complex a Mode 1 or Mode 3 phenomenon? A morphometric assessment. Journal of Archaeological Science. 2007;34:1434-1440.

23. Gill WD. The stratigraphy of the Siwalik Series in the Northern Potwar, Pakistan. Quaternary Journal of the Geological Society. 1951;107:375394

24. Sankalia HD. Is the Soan a flake industry? J Asiat Soc. 1957;22:161-62.

25. Chauhan PR. Soanian cores and core-tools from Toka, Northern India: Towards a new typo-technological organization. Journal of Anthropological Archaeology. 2007;26(3):412-441.

26. Chauhan PR. Soanian lithic occurrences and raw material exploitation in the Siwalik Frontal Zone, northern India: a geoarchaeologica perspective. Journal of Human Evolution. 2008;54:591-614.

27. Soni AS, Soni VS, Dhillon DS. Large assemblages of flakes \& cores found on dated young terraces of River Satluj and its tributaries. Current Science. 2008;94(5):577-580.

28. Soni AS, Soni VS. A flake-rich assemblage in buried state and in primary context in the NW sub-Himalayas. Current Science. 2009;96:1130-1133.

29. Soni VS, Soni AS. Large size cleaver-like flakes and Hoabinhoida elements from terminal Pleistocene to mid-Holocene epoch sites. Quaternary International. 2010;223-224:242-244.

30. Soni AS, Soni VS. Pitted Cobbles in the Northwestern Indian subHimalayas. Antiquity Project Gallery. 2011;85(328).

31. Soni AS, Soni VS. Pitted cobbles from mid-Holocene sites of NW sub-Himalayas of India. Journal of Archaeological Science: Reports. 2016;6:557-573 
32. Soni VS, Soni AS. On the Late Pliocene stone tools of the Quranwala Zone, north-west sub-Himalayas, India. Antiquity, Project Gallery. 2017;91(357):e1.

33. Nauriyal KC, Sharma VC, Ota SB, et al. Significance and implications of Large Lithic Artefacts from Bara in Late Harappan Context. Paper presented in International Conference on Harappan Archeology, Chandigarh, India; 2012.

34. Gaillard C, Singh M, Malassé AD, et al. The lithic industries on the fossiliferous outcrops of the Late Pliocene Masol Formation, Siwalik Frontal Range, northwestern India (Punjab). CR Palevol. 2016;15(34):341-357.

35. Giosan L, Clift PD, Macklin MG, et al. Fluvial landscapes of the Harappan civilization. PNAS. 2012;109(26):E1688-E1694.

36. Staubwasser M, Weiss H. Holocene climate and cultural evolution in the late prehistoric-early historic West Asia. Quaternary Research. 2006;66:372-387.

37. Possehl GL. The Transformation of the Indus civilization. Journal of World Prehistory. 1997;11:425-472.

38. Kumar M. Linguistics, Archaeology and the Human Past, Occasional Paper 7. In: Osada T, Uesugi A, editors. Japan: Nakanishi Printing Co. Ltd; 2009.

39. Wright RP, Schuldenrein J, Mughal MR. In: Jarrige C, Lefèvre V, editors. South Asian Archaeology. Paris: CNRS; 2005. p. 327-336.

40. SI. Excavation Sites in Punjab-Archaeological Survey of India. Delhi, India; 2011.

41. Agrawal DP, Kusumgar S. Tata Institute Radiocarbon date list X Radiocarbon. 1973;15(3):574-585.

42. Sharma YD. Cultural Contours of India. Dr. Satya Prakash Felicitation Volume: 17-20. In: Srivastva VS, editor. India: Abhinav Publications; 1981.
43. Prufer O. The Prehistory of the Sirsa Valley, Punjab, India. Quartar. 1956;7/8:91-123.

44. Gupta AK, Anderson DM, Pandey DN, et al. Adaptation and human migration, and evidence of agriculture coincident with changes in the Indian summer monsoon during the Holocene. Current Science. 2006;90:1082-1090.

45. Shinde V, Deshpande SS, Osada T, et al. Basic Issues in Harappan Archeology: Some Thoughts. Ancient Asia. 2006;1:63-72.

46. Breschini GS, Haversat T. Pitted stones from CA-SLO-697 and CASLO-762, Cambria, San Luis Obispo County, California. 1993.

47. Fitzgerald RT, Jones TL. The Milling Stone Horizon revisited: new perspectives from northern and central California. Journal of California and Great Basin Anthropology. 1999;21(1):67-93.

48. Adams B. The Stemler Bluff site: lithic analysis at late Woodland to Mississippian occupation overlooking the American Bottom. Illinois Antiquity. 2001;36(3):11-17.

49. Ha Van Tan. The Hoabinhian and before. IPPA Bulletin. 1997;16:36-41.

50. Bellwood P. Prehistory of Indo-Malaysian Archipelago. Australia: Australian National University Press; 2007.

51. Possehl GL, Kennedy KAR. Hunter-Gatherer/Agriculturist Exchange in Prehistory: An Indian Example. Current Anthropology. 1979;20:591593

52. Soni AS, Soni VS. Palaeolithic tools from the surface of optically stimulated luminescence dated alluvial fan deposits of Pinjaur Dun in NW sub-Himalayas. Current Science. 2005;88:867-871. 